\title{
Kedudukan Audit Medis dalam Penegakan Hukum Tindak Pidana di Bidang Medis
}

\author{
Hamdani Abubakar \\ Program Pascasarjana Fakultas Hukum Universitas Islam Indonesia \\ Jln. Cik Di Tiro No. 1, Yogyakarta, 55223 \\ danistricta@gmail.com
}

\begin{abstract}
This study examines the status of Medical Audit in law enforcement in the medical field, and to what extend can Medical Audit be used as evidence in court proceedings. The concept of this research is juridical-empirical, with descriptive-qualitative study, the method used is literature and interviews, relying on legislation relating to health services in hospitals. This study uses a theory consisting of health legal instruments relating to ethics and law, Hospital Law, Medical Records, Medical Audits, Professional Standards, and Operational Procedure Standards, as well as materials for criminal actions and criminal accountability. The results showed that Medical Audit can be applied in investigations and inquisitions by the police. However, the police do not use Medical Audit as an instrument of enforcement and verification, whilst it is very crucial in assessing a certain relevant issue. Law enforcement is expected to be able to make the Medical Audit as part of the admissible evidence in the Police.
\end{abstract}

Keywords: Medical audit; police; criminal law enforcement

\begin{abstract}
Abstrak
Penelitian ini bertujuan mengkaji kedudukan audit medis dalam penegakan hukum tindak pidana di bidang medis, dan sejauh mana Audit Medis dapat dipakai sebagai bukti di persidangan. Konsep penelitian ini adalah yuridis-empiris, dengan jenis penelitian deskriptif-kualitatif, metode yang digunakan adalah kepustakaan dan wawancara, bertumpu pada peraturan perundang-undangan yang berhubungan dengan pelayanan kesehatan di Rumah Sakit khususnya Komite Medik di Rumah Sakit. Penelitian ini menggunakan kerangka teori yang terdiri dari instrumen hukum kesehatan seperti etika dan hukum, Hukum Rumah Sakit, Rekam Medis, Audit Medis, Standar Profesi, dan Standar Prosedur Operasional, serta materi perbuatan pidana dan pertanggung jawaban pidana. Hasil penelitian menyimpulkan audit medis dapat diterapkan dalam penyelidikan dan penyidikan di kepolisian. Namun, kepolisian tidak menggunakan Audit Medis sebagai instrumen penegakan dan pembuktian, Padahal kedudukannya sangat penting dalam melihat sebuah permasalahan. Diharapkan penegak hukum, untuk dapat menjadikan Audit Medis sebagai bagian pembuktian di Kepolisian.
\end{abstract}

Kata-kata Kunci: Audit medis; kepolisian; penegakan hukum pidana 


\section{Pendahuluan}

Kesehatan adalah kebutuhan yang bersifat primer bagi manusia, kedudukan yang begitu penting dalam setiap pola aktivitas kegiatan manusia, ketika kesehatan manusia itu terganggu atau menurun/sakit, maka akan berpengaruh pada aktivitas manusia tersebut. oleh karena itu kesehatan merupakan hal yang bersifat kodrati, manusia berusaha dan berikhtiar untuk bagaimana bisa berada pada tataran atau keadaan yang baik, berbagai instrumen yang dilakukan oleh manusia, penelitian, pengembangan ilmu pengetahuan di bidang kesehatan dan lain sebagainya, untuk menjaga agar kesehatan manusia tetap baik.

Oleh karena itu dalam perkembangannya, maka dilakukanlah sejumlah penelitian atau penemuan dan pengembangan ilmu pengetahuan di bidang kesehatan terus berlanjut dilakukan, seiring dengan perkembangan manusia yang menuju pada proses yang begitu kompleks dan modern, urgensi kompleksitasnya manusia tentu bukanlah hal mudah dalam menyikapinya, karena di sini bertemu dengan berbagai kepentingan manusia yang bukan saja mengejar pada titik akhir suatu kesehatan yaitu sembuh dari sakit, melainkan terdapat sejumlah persoalan lain, dari sejak proses penanganannya di rumah sakit, terhadap orang/pasien, sampai pada akhirnya sembuh atau malah meninggal dunia.

Sejak 460 tahun Sebelum Masehi, sudah ada upaya dari Hippocrates untuk merasionalisasikan kegiatan ilmu kedokteran. Upaya itu dilakukan dengan menekankan arti pentingnya "pengobatan dan kemanusiaan" sebagaimana terdapat dalam kandungan dalil kedokteran. Perkembangan ilmu pengobatan memang mengalami perubahan dari sifatnya yang mistis ke arah moralitas dan paternalistis pada abad ke-15, selanjutnya pada abad ke-18 sampai abad ke-19 terjadi perubahan kegiatan ilmu kedokteran, memasuki abad ke-20 bidang kedokteran mulai meluas menjadi kesehatan sehingga hukum kedokteran diperluas menjadi hukum kesehatan, yang ditandai dengan perubahan sosial tentang "hak asasi manusia", dan sejak itu tumbuh hubungan kontraktual, puncaknya kepentingan hak asasi manusia yang berhubungan dengan kesehatan dimulai dari tiga hak asasi meliputi, right to haelthcare (hak mendapat pelayanan 
kesehatan), right to self determination (hak mengambil keputusan secara mandiri), dan right to information (hak untuk mendapat informasi). ${ }^{1}$

Keberadaan hak di atas dalam penanganan pelayanan kesehatan terhadap manusia atau setiap orang di Indonesia, telah termanifestasikan dan bertumpu pada dasar ketentuan UUD 1945 Pasal $28 \mathrm{H}$, dinyatakan bahwa; setiap orang berhak hidup dan mendapatkan lingkungan hidup yang baik dan sehat, serta berhak memperoleh pelayanan kesehatan. Selanjutnya, dalam Pasal 34 ayat (3) UUD 1945, dijelaskan bahwa, negara bertanggung jawab atas penyediaan fasilitas pelayanan kesehatan dan fasilitas umum yang layak. Ini berarti bahwa pelayanan kesehatan adalah hak bagi setiap orang dan negara wajib menyediakan fasilitas kesehatan yang memadainya bagi setiap warga masyarakat. Implikasinya bahwa setiap warga masyarakat seharusnya berhak mendapatkan pelayanan kesehatan sesuai dengan kebutuhan medis dan membayar sesuai dengan kemampuan. ${ }^{2}$

Lahirnya hak dan dari segala bentuk problematika kesehatan yang begitu kompleks, di dalamnya terkandung tiga komponen penting, yaitu Rumah Sakit, Dokter, dan Pasien. Ketiganya mempunyai keterkaitan satu dengan yang lain, rumah sakit mempunyai ketentuan tunduk terhadap UU Rumah Sakit serta pembuatan kebijakan di dalamnya (hospital by law), dan dokter tunduk pada UU kedokteran, kebijakan rumah sakit, serta pelayanan kepada masyarakat/pasien, sedangkan pasien menjalankan hak dan kewajibannya untuk mendapatkan pelayanan dari dokter dan rumah sakit, sebagaimana tertuang dalam UndangUndang Kesehatan.

Pelayanan kesehatan (healthcare) di dalamnya ditemukan dua kelompok yang perlu dibedakan, pertama, healthcare receivers, yaitu penerima layanan kesehatan yang termasuk dalam kelompok ini misalnya pasien, orang yang menderita sakit, mereka yang ingin memelihara kesehatan, ingin diberi vaksin, orang hamil yang memeriksa kandungannya. Kedua, healthcare provider, yaitu dokter dan tenaga

\footnotetext{
${ }^{1}$ Hendrik, Etika \& Hukum Kesehatan, Penerbit Buku Kedokteran EGC, Jakarta, 2011, hlm. 15-16.

2 Marel Seran \& Anna Maria Wahyu Setyowati, Dilema Etika Dan Hukum Dalam Pelayanan Medis, Penerbit CV. Mandar Maju, 2010, hlm. 11.
} 
kesehatan, apoteker, bidan, perawat, analisis laboratorium kesehatan, ahli gizi dan lain-lain. ${ }^{3}$

Kedua kelompok dalam hal pelayanan kesehatan tersebut di atas apabila dilihat secara konkret, seperti persoalan penanganan antara dokter terhadap pasien di rumah sakit, banyak mengandung dilema misalnya, di lihat dari sudut pandang masyarakat banyak yang menganggap bahwa, perawatan paliatif hanya pada pasien dalam kondisi terminal yang akan meninggal, artinya bahwa masyarakat lebih memilih melakukan pengobatan setelah penyakit yang diderita sudah mencapai batas akhir dalam pengobatan, yang mana apabila diobati harus membutuhkan dana besar, berakibat fatal dan sebagainya, namun konsep baru perawatan paliatif menekankan pentingnya integrasi perawatan paliatif lebih dini agar masalah fisik, psiko-sosial dan spiritual dapat diatasi dengan baik. selain pengobatan untuk berusaha menyembuhkan penyakitnya, juga diberikan perawatan agar mencapai kualitas hidup yang terbaik bagi pasien dan keluarganya. ${ }^{4}$

Tindakan ini menjadi tanggung jawab penuh bagi tenaga kesehatan dokter, perawat dan pihak rumah sakit, namun perjalanannya terdapat masalah, karena salah satu di antaranya, yaitu pihak rumah sakit akan berhadapan dengan berbagai permasalahan-permasalahan seperti, yang dihadapi oleh rumah sakit baik itu rumah sakit milik pemerintah, yayasan maupun swasta, secara umum dapat dibagi menjadi tiga hal, yakni pengelolaan keuangan, standar pelayanan (mutu dan keselamatan pasien) dan pelayanan BPJS (national coverage). 5

Standar pelayanan medis (mutu dan keselamatan pasien) dalam konteks ini salah satunya ialah Audit Medis. Yang terbagi menjadi dua bagian yaitu Audit Medis Internal dan Audit Medis External, Audit Medis sendiri merupakan serangkaian pengauditan sebagai upaya evaluasi secara profesional terhadap mutu pelayanan medis yang diberikan kepada pasien dengan menggunakan rekam medis, pelaksanaan Audit Medis dilakukan oleh profesi medis. Walaupun Audit

\footnotetext{
${ }^{3}$ Moh. Hatta, Hukum Kesehatan \& Sengketa Medik, Penerbit Liberty Yogyakarta, Yogyakarta, 2013, hlm. 27.

${ }^{4}$ Sutarno, Hukum Kesehatan (Eutanasia, Keadilan dan Hukum Positif di Indonesia), Penerbit Setara Press, Malang, Jatim, 2014.

5 "Manajemen Administrasi Rumah Sakit" https://rsadministrasi.wordpress.com/2015/12/22/ permasalahan-rumah-sakit/
} 
Medis tidak diatur secara eksplisit di dalam UU Praktik Kedokteran, tetapi dokter sebaliknya juga harus memahami Audit Medis, karena dalam melaksanakan praktik kedokteran, dokter juga wajib menyelenggarakan kendali mutu dan kendali biaya, yang terhadap pelaksanaan kendali mutu dan kendali biaya ini, dapat dilakukan Audit Medis sebagaimana tertuang di dalam Pasal 49 ayat (1) dan ayat (2) UU Praktik Kedokteran.

Salah satu isu utama bagi kami penulis adalah Audit Medis dalam hal persoalan standar pelayanan (mutu dan keselamatan pasien) karena hal ini menjadi andil dalam hubungan terapeutik antara dokter dan pasien beserta rumah sakit, contoh kasus misalnya di bawah ini, seperti yang terjadi di bulan September 2017 kemarin, publik dikagetkan dengan suatu persoalan kesehatan di rumah sakit, di mana meninggalnya bayi yang bernama Debora ${ }^{6}$ anak dari Henny Silalahi dan Rudianto Simanjorang, di RS Mitra Keluarga Kalideres, karena diduga tak punya uang muka, perihal ini dibantah oleh pihak rumah sakit karena pihak rumah sakit sudah melakukan pertolongan dengan prosedur yang ditetapkan. Atas kasus ini pihak Dinas Kesehatan DKI Jakarta membentuk tim dan melakukan investigasi Audit Medis dan Audit Manajemen RS Mitra Keluarga Kalideres, yang diisi oleh lembaga profesi Ikatan Dokter Indonesia (IDI). Dari hasil Audit Medis yang dilakukan, dinyatakan bahwa, pihak dokter telah melakukan penanganan terhadap bayi Debora dengan baik.

Pelaksanaan Audit Medis sebagaimana yang dijelaskan di atas, hal ini bersesuaian dengan pengertian dan tujuan Audit Medis, dalam Peraturan Menteri Kesehatan Republik Indonesia Nomor755/Menkes/Per/Iv/2011 Tentang Penyelenggaraan Komite Medik di Rumah Sakit, BAB I Pasal 1 Ayat 11 menyatakan bahwa, "Audit Medis adalah upaya evaluasi secara profesional terhadap mutu pelayanan medis yang diberikan kepada pasien dengan menggunakan rekam medisnya yang dilaksanakan oleh profesi medis." Tujuannya ialah mengatur tata kelola klinis (clinical governance) yang baik agar mutu pelayanan medis dan

6 "RS Mitra Keluarga Bayi Debora Tak Masuk PICU Karena Belum Stabil" Kompas.com, http://megapolitan.kompas.com/read/2017/09/22/17300811/rs-mitra-keluarga-bayi-debora-tak-masuk-picukarena-belum-stabil 
keselamatan pasien di rumah sakit lebih terjamin dan terlindungi serta mengatur penyelenggaraan komite medik di setiap rumah sakit dalam rangka peningkatan profesionalisme staf medis.

Mekanisme Audit Medis dilakukan oleh profesi medis yaitu komite medis, ketika terjadi sebuah permasalahan atau penyimpangan dalam proses tindakan medis atau penyembuhan dari rumah sakit yaitu dokter kepada pasien, maka hasil Audit Medis dibawa ke bagian Mitra Bestari (peer group) untuk dinilai berdasarkan kompetensi profesi yang baik, dari hasil ini kemudian dinilai salah atau tidak, tindakan dokter di rumah sakit oleh komite medik, etik, dan hukum, dalam bentukan rekomendasi.

Permasalahan, pengertian dan mekanisme Audit Medis di atas, sesungguhnya telah menjelaskan atau menjawab permasalahan dari pihak rumah sakit, dokter, dan pasien, di mana komite medik yang menjalankan kewenangannya sesuai dengan Peraturan Menteri Kesehatan (Permenkes) dan mampu memberikan rekomendasi penyelesaian yang baik dan tidak merugikan di semua pihak, namun bagaimana ketika persoalan ini telah dilakukan pada ranah kepolisian dapatkah Audit Medis, menjadi bagian dalam kebijakan penegakan hukum pidana di bidang kesehatan. Karena dari sebagian literatur menjelaskan bahwa, penegakan hukum pidana pada tingkat kepolisian tidak menggunakan sarana Audit Medis dalam proses penegakan hukum yang mereka lakukan.

Penegakan hukum pidana apabila dilihat dalam suatu proses kebijakan, penegakan hukum pidana pada hakikatnya merupakan penegakan kebijakan yang melalui tiga tahap, pertama tahap formulasi yaitu tahap legislatif yaitu tahapan penegakan hukum in abstracto oleh pembuat undang-undang, kedua, tahap aplikasi atau yudikatif, yaitu tahapan penerapan hukum pidana oleh aparat-aparat penegakan hukum mulai dari kepolisian sampai pada pengadilan, dan ketiga, yaitu pelaksanaan hukum pidana secara konkret oleh aparat-aparat pelaksana pidana/eksekusi kepada para pembuat tindak pidana atau melanggar hukum. ${ }^{7}$

Tindak pidana sendiri merupakan suatu perbuatan yang dilarang oleh suatu aturan hukum, larangan mana disertai ancaman (sanksi) yang berupa pidana

\footnotetext{
${ }^{7}$ Teguh Prasetyo, Kriminalisasi dalam Hukum Pidana, Penerbit Nusa Media, Bandung, 2010, hlm. 111.
} 
tertentu bagi barang siapa melanggar larangan tersebut ${ }^{8}$. Jika dihubungkan dengan Frasa Bidang kesehatan menjadi tindak pidana di bidang kesehatan jadi dari pengertian ini bahwa setiap tindakan yang merupakan bentukan medis maka disebut tindakan medis, kapan dan bagaimana dapat di pidana suatu tindakan medis tersebut, ketika perbuatan tersebut menyerang kepada kepentingan hukum yang dilindungi, nyawa/jiwa, badan, kehormatan, kemerdekaan, dan harta benda. ${ }^{9}$

Penentuan dalam hal menentukan kesalahan medis pada tindak pidana medis dalam praktik kedokteran bukanlah hal yang mudah, eksistensi keilmuan kedokteran yang bersifat spekulatif sulit dan tak mudah begitu saja diterapkan, dikarenakan tindakan penyembuhan penyakit pada pasien belum tentu dapat menjamin kesehatan pasien sembuh secara menyeluruh, begitu juga di sisi lain profesi kedokteran begitu berbeda dengan profesi lainnya, disebabkan karena keilmuan kesehatan atau kedokteran harus memiliki keahlian khusus yang harus melalui rangkaian tahapan pendidikan yang panjang.

Berdasarkan uraian di atas, maka penulis akan mengkaji terkait dengan aspek hukum Audit Medis dalam kedudukannya terhadap tindak pidana di bidang medis, terutama peran Audit Medis dalam hal perlindungan kepada Dokter dan Rumah sakit.

\section{Rumusan Masalah}

Berdasarkan pendahuluan di atas maka rumusan masalah pada penelitian ini adalah: pertama, bagaimana kedudukan Audit Medis dalam penegakan hukum Tindak Pidana di bidang Kesehatan? Kedua, bagaimana penggunaan hasil Audit Medis untuk pembuktian dalam tindak pidana di bidang medis?

\section{Tujuan Penelitian}

Dalam setiap kegiatan penelitian selalu mempunyai tujuan tertentu, dari penelitian ini diharapkan dapat menjawab permasalahan Audit Medis yang terjadi,

\footnotetext{
${ }^{8}$ Prof Molejatno di kutip di dalam Ismu Gunadi \& Jonaedi Efendi, Cepat dan Mudah Memahami Hukum Pidana, Penerbit Kencana Prenada Media Group, Jakarta, 2014, hlm. 37.

9 Teguh Prasetyo, Hukum Pidana Materil, Penerbit Kurnia Kalam Yogyakarta, Yogyakarta, 2005, hlm. 28.
} 
sehingga dapat memberi manfaat bagi pihak-pihak yang terkait dengan penelitian ini. Adapun tujuan dari penelitian ini adalah sebagai berikut: pertama, untuk mengkaji dan mengetahui kedudukan Audit Medis dalam penegakan hukum tindak pidana di bidang medis. Kedu, untuk mengetahui sejauh manakah bentukan Audit Medis dapatkah dipakai sebagai bahan pembuktian dalam tindak pidana di bidang medis.

\section{Metode Penelitian}

Penelitian ini merupakan penelitian hukum yang termasuk dalam tipologi penilitian hukum normatif/doktrinal. Adapun pendekatan yang digunakan dalam penelitian ini adalah pendekatan undang - undang. Objek dalam penelitian ini adalah hukum yang dikonsepkan sebagai apa yang tertulis dalam peraturan perundang-undangan yang dibuat oleh lembaga yang berwenang, dalam bentuk peraturan - peraturan yang mengatur tentang Audit Medis, Rekam Medis, Informed Consent, standar profesi dan standar prosedur operasional, serta peraturan perundang-undangan terkait lainnya dalam hubungan dengan pelayanan kesehatan di Rumah sakit khususnya Komite Medik di Rumah Sakit. Digunakannya pendekatan tersebut, dengan tujuan agar dapat diketahui terkait dengan aspek-aspek hukum Audit Medis dalam kedudukannya sebagai formula awal dalam konteks tindak pidana, apabila terjadi perbuatan yang tidak dinginkan dalam tindakan kesehatan (lege artis) seperti kegagalan, kecacatan, luka pada tubuh, atau mati pada pasien. Lebih mendalam lagi, penelitian ini diharapkan dapat mengungkap permasalahan hukum terkait dengan kedudukan Audit Medis apabila terjadi peristiwa kegagalan yang disebabkan oleh tindakan medis (lege artis).

\section{Hasil Penelitian dan Pembahasan}

\section{Kedudukan Audit Medis dalam Konteks Undang-Undang dan Doktrinal}

Audit medis merupakan sarana untuk mengevaluasi setiap tindakan medis yang dilakukan oleh pihak rumah sakit melalui mekanisme komite medis di Rumah Sakit. Penyelenggaraan Audit Medis dilakukan dalam rangka menjaga kendali mutu dalam ruang lingkup pelayanan kesehatan. Semua tindakan tenaga 
kesehatan baik itu dokter, perawat, maupun petugas kesehatan lainya, dalam melakukan pelayanan kesehatan, penilaian ataupun pengukuran, peningkatan sebuah kualitas pelayanan, oleh rumah sakit dapat dilihat dari sebuah bentukan Audit Medis.

Dasar hukum pelaksanaan Audit Medis, Audit Medis termaktub dalam UU Kedokteran Pada Pasal 49 ayat (1) setiap dokter dan dokter gigi dalam melaksanakan praktik kedokteran atau kedokteran gigi wajib menyelenggarakan kendali mutu dan kendali biaya. Ayat (2) dalam rangka pelaksanaan kegiatan sebagaimana dimaksud pada ayat (1) dapat diselenggarakan Audit Medis. Begitu pun dalam UU Rumah Sakit menekankan agar rumah sakit menyelenggarakan Audit Medis dan audit kinerja, adanya tindakan ini dalam rangka kualitas, perlindungan kepada pasien dan pemenuhan pelayanan rumah sakit. Berdasarkan pada bentukan UU di atas maka eksistensi Audit Medis menjadi suatu kegiatan penting dalam menilai setiap tindakan medis.

Ketentuan Undang-Undang di atas di jelaskan lebih lanjut dalam, Peraturan Menteri Kesehatan Republik Indonesia Nomor 755/Menkes/Per/Iv/2011 tentang Penyelenggaraan Komite Medis di Rumah Sakit, menjelaskan bahwa Audit Medis adalah upaya evaluasi secara profesional terhadap mutu pelayanan medis yang diberikan kepada pasien dengan menggunakan rekam medisnya, yang dilaksanakan oleh profesi medis.

Ketentuan audit terhadap undang-undang di atas menjadi hukum bagi setiap tenaga medis di rumah sakit dan rumah sakit dalam melaksanakan pelayanan medis, baik rawat jalan maupun rawat inap. Pelaksanaan Audit Medis dimaksud dalam rangka, meningkatkan mutu dan kualitas agar pelayanan medis, dalam hal penanganan kepada perlindungan setiap pasien dapat berjalan dengan baik. Sebagaimana yang menjadi maksud daripada regulasi yang ada di atas.

Di sisi lain, secara konteks doktrinal Audit Medis pun dilakukan karena merupakan standar ketentuan dalam hal penilaian setiap tindakan kedokteran, dalam melakukan tindakan medis di Rumah Sakit ataupun pada praktik sendiri. pelaksanaan Audit Medis tetap dilakukan demi Menjaga mutu atau kualitas, 
perlindungan kepada pasien ${ }^{10}$ serta perbaikan pelayanan di rumah sakit. Bagaimana kita dapat mengetahui daripada sebuah tindakan tenaga medis atau dokter di rumah sakit apakah hal itu berdasarkan pada standar profesi dan standar prosedur operasional di rumah sakit. ${ }^{11}$

Oleh sebab itu pelaksanaan Audit Medis tersebut, di rumah sakit mempunyai peran penting dan strategis dalam hal pelayanan medis kepada pasien di rumah sakit, terselenggaranya sebuah tindakan yang baik dan berpedoman pada standar operasional rumah sakit, semua itu dapat dilihat dalam mekanisme Audit Medis oleh komite medis di rumah sakit.

Pelaksanaan Audit Medis dilakukan oleh 2 lembaga yang berbeda yakni oleh komite medis di Rumah Sakit dan pihak organisasi kesehatan yaitu Ikatan Dokter Indonesia (IDI). Audit medis di rumah sakit dapat dilakukan oleh pihak komite medis di rumah sakit, hal ini sebagai bahan evaluasi dari semua tindakan medis yang dilakukan oleh dokter. Sedangkan Audit Medis yang dilakukan oleh pihak IDI harus berdasarkan, pada pengaduan ketika terjadi kasus atau penyimpangan yang diduga dilakukan oleh pihak dokter itu sendiri. ${ }^{12}$

Hal ini berarti Audit Medis, dapat menjadi jalan dan batu uji dalam menjawab sebuah permasalahan, ketika terdapat kasus hukum atau penyimpangan yang terjadi, ketika tenaga medis atau dokter melakukan pelayanan kesehatan atau pelayanan medis kepada pasien.

Tindakan dokter di rumah sakit dilakukan berdasarkan pada standar profesi dan standar prosedur operasional di rumah sakit, karena hal inilah yang menjadi sumber tindakan oleh dokter kepada pasien. Tindakan tersebut mengandung pengetahuan, ketrampilan ataupun perilaku (knowledge, skills, attitude), dokter di dalam hal bertindak, bahkan dalam ketentuan UU No. 36 Tahun 2014 tentang Kesehatan, Pasal 66 menekankan untuk mewajibkan kepada tenaga medis patuh terhadap standar profesi dan standar prosedur operasional. Hal ini berarti setiap tindakan yang dilakukan oleh tenaga medis berdasar pada standar profesi dan

\footnotetext{
${ }^{10}$ Hasil wawancara dengan pihak IDI Cabang Yogyakarta.

${ }^{11}$ Fred Ameln, Op. Cit., hlm. 92.

${ }^{12}$ Hasil wawancara dengan pihak IDI.
} 
standar prosedur operasional, tindakan ini dapat dipandang sebagai yuridis formil dalam setiap tindakan kedokteran (lege artis) atau tenaga medis.

Pengertian standar profesi sendiri dalam Pasal 1 Ketentuan Umum UU No. 36 Tahun 2014 tentang Kesehatan, Butir 12, Standar Profesi adalah batasan kemampuan minimal berupa pengetahuan, keterampilan, dan perilaku profesional yang harus dikuasai dan dimiliki oleh seorang individu untuk dapat melakukan kegiatan profesionalnya pada masyarakat secara mandiri yang dibuat oleh organisasi profesi bidang kesehatan. Sedangkan pada butir ke 14 selanjutnya pengertian Standar Prosedur Operasional adalah suatu perangkat instruksi/langkah-langkah yang dibakukan untuk menyelesaikan proses kerja rutin tertentu dengan memberikan langkah yang benar dan terbaik berdasarkan konsensus bersama untuk melaksanakan berbagai kegiatan dan fungsi pelayanan yang dibuat oleh Fasilitas Pelayanan Kesehatan berdasarkan Standar Profesi.

Dapat dipahami standar profesi yang berisi tentang kemampuan pengetahuan ketrampilan dan perilaku profesional oleh dokter/tenaga medis, hal diaplikasikan dalam bentuk standar pelayanan, menurut Ketentuan mengenai standar pelayanan, Permenkes Nomor 1438/Menkes/PER/IX/2010, Tentang Izin Standar Pelayanan Kedokteran adalah "Pedoman yang harus diikuti oleh dokter dan dokter gigi dalam menyelenggarakan praktik kedokteran. ${ }^{13}$ Standar pelayanan kedokteran harus disusun secara sistematis dengan menggunakan pilihan pendekatan yaitu pengelolaan penyakit dalam kondisi tunggal (tanpa penyakit lain atau komplikasi) serta pengelolaan berdasarkan kondisi. Selain itu, standar pelayanan kedokteran harus dibuat dengan bahasa yang jelas, tidak bermakna ganda, menggunakan kata bantu kata kerja yang tepat, mudah dimengerti, terukur dan realistis. ${ }^{14}$

Standar Pelayanan Kedokteran harus sahih pada saat ditetapkan, mengacu pada kepustakaan terbaru dengan dukungan bukti klinis, dan dapat berdasarkan hasil penapisan ilmu pengetahuan dan teknologi kedokteran yang dilaksanakan

${ }^{13}$ Lihat Permenkes No 1438/Menkes/Per/IX/2010.

14 Desriza Ratman, Aspek Hukum Penyelenggaraan Praktek Kedokteran dan Malpraktek Medik, Op Cit. hlm. 12. 
oleh Kementerian Kesehatan atau institusi pendidikan kedokteran. ${ }^{15}$ Standar Pelayanan Kedokteran meliputi pedoman Nasional Pelayanan Kedokteran (PNPK) dan Standar Prosedur Operasional (SPO).

Oleh sebab itu, dalam ketentuan UU Kesehatan di atas dapat dimengerti, bahwa tindakan tenaga medis harus berdasar pada Standar Profesi dan Standar Prosedur Operasional. Maka rekam medis merupakan bentukan dari semua tindakan tenaga medis dan pelayanan medis kepada pasien yang tertulis atau terekam, patut dikatakan Audit Medis, merupakan manifestasi dari Standar Profesi dan Standar Prosedur Operasional karena Audit medis berdasar pada rekam medis dan rekam medis terlaksana berdasarkan pada tindakan standar profesi dan standar prosedur operasional tenaga medis, kepada pasien.

Penggunaan sarana Audit Medis untuk rekam medis merupakan suatu konsekuensi logis dari semua tindakan dokter dalam melakukan tindakan medis, karena untuk menentukan suatu kesalahan atau kelalaian yang dilakukan oleh seorang dokter, sangatlah sukar untuk ditemukan dan diterapkan. Seperti yang diketahui, untuk menilai bahwa tindakan dalam hal standar profesi medis yang dilakukan oleh dokter, didalamnya ditentukan dengan adanya ketentuan tindakan secara teliti, sesuai ukuran medis, kemampuan rata-rata dibandingkan dengan dokter lain, dan suatu kondisi yang sama, serta upaya perbandingan yang wajar. Semua itu tidak bisa dilihat dan dinilai secara individu atau subjektif, 16 untuk mengatakan tindakan dokter tersebut bersalah.

Prof H .J.J Leenen, ${ }^{17}$ menjelaskan bahwa tindakan medis disebut lege artis jika tindakan tersebut telah dilakukan sesuai dengan standar profesi dokter yaitu bahwa yang disebut dengan standar profesi medis adalah "suatu tindakan medis seorang dokter, sesuai dengan standar profesi kedokteran jika dilakukan secara teliti sesuai ukuran medis, sebagai seorang dokter yang memilik kemampuan ratarata dibandingkan dengan dokter dari kategori keahlian medis yang sama dengan sarana upaya yang memenuhi perbandingan yang wajar (proporsional) dibandingkan dengan tujuan konkret tindakan medis tersebut."

\footnotetext{
${ }^{15}$ Lihat Permenkes No 1438/Menkes/Per/IX/2010.

${ }^{16}$ Hasil Wawancara dengan pihak komite medis di RS Panti Rapih.

${ }^{17} \mathrm{Hj}$. Endang Kusuma Astuti, Op. Cit. hlm. 29.
} 
Semua ukuran atau patokan di atas hanyalah dapat dibuktikan dengan mekanisme Audit Medis, karena untuk menentukan tindakan dokter yang sesuai dengan profesi medis seperti tindakan yang teliti dan sesuai dengan ukuran medis, penilaian tindakan dokter yang sesuai dengan kemampuan rata-rata dibandingkan dengan dokter dari kategori keahlian medis yang sama, situasi dan kondisi yang sama, serta dengan sarana upaya yang memenuhi perbandingan yang wajar dibandingkan dengan tujuan konkret tindakan medis tersebut, sangatlah sulit dan dapat menimbulkan kesalahan apabila tidak dilihat dengan baik. Oleh sebab itu, yang dapat menemukan, menilai, dan menjelaskan ataupun menggambarkan tindakan dokter atau tenaga medis untuk sesuai dengan standar prosedur dan standar prosedur operasional di dalam rekam medis adalah Audit Medis, yang di dalamnya terdapat sebuah tim yang ahli di bidang medis.

Adanya tim ahli di dalam Mekanisme Audit Medis tersebut menjadi jawaban dalam menemukan kesalahan dan kelalaian dokter dalam tindakan medis tersebut. karena di dalamnya terdapat perkumpulan dokter atau Mitra bestari (peer group)18, yaitu sekelompok staf medis dengan reputasi dan kompetensi profesi yang baik untuk menelaah segala hal yang terkait dengan profesi medis. ${ }^{19}$ Oleh sebab itu, ukuran ketelitian ataupun kemampuan rata- rata, atau sebagimana yang dijelaskan oleh J Lennen, dapat ditemukan oleh semua perkumpulan dokter atau mitra bestari (peer group) itu, berdasar pada standar keilmuan yang mereka miliki. ${ }^{20}$

Artinya ketentuan dalam standar profesi medis seperti tindakan yang teliti, kemampuan rata-rata, kondisi yang sama serta perbandingan yang wajar dapat berbanding lurus dan sama ketika dinilai sama oleh dokter atau perkumpulan dokter (peer group) yang melakukan tindakan teliti, dan diukur oleh kemampuan rata-rata oleh perkumpulan dokter tersebut, serta dapat dibandingkan dengan dokter atau perkumpulan dokter yang pernah melakukan tindakan dokter yang sama.

18 Lihat Permenkes Nomor 755/Menkes/Per/Iv/2011 Tentang Penyelenggaraan Komite Medik Di Rumah Sakit

${ }^{19}$ Lihat Permenkes Nomor 755/Menkes/Per/Iv/2011 Tentang Penyelenggaraan Komite Medik di Rumah Sakit, Bab 1 Ketentuan Umum Pasal 1 Butir 12.

${ }^{20}$ Hasil Wawancara dengan pihak Komite Medik RS Panti Rapih. 
Sehingga hasil akhir yang ditemukan, bahwa dokter yang bersangkutan tidak teliti dalam tindakan medisnya dapat menjadi benar karena dinilai oleh Peer Group yang rata-rata sama dalam melihat ketelitian tindakan dalam kasus kesehatan yang sama, adapun sama halnya juga kemampuan rata-rata dapat dinilai jelas oleh tim Audit Medis karena hal itu dinilai oleh sekumpulan dokter yang mempunyai kemampuan yang sama rata-rata, begitu pun situasi dan kondisi yang sama, juga dapat dinilai benar karena dinilai pada perkumpulan dokter yang sama dan juga pada kondisi yang sama.

\section{Penegakan Hukum Audit Medis dalam Tindak Pidana Medis}

Penegakan hukum pidana apabila dilihat dalam suatu proses kebijakan, penegakan hukum pidana pada hakikatnya merupakan penegakan kebijakan yang melalui tiga tahap, pertama tahap formulasi yaitu tahap legislatif yaitu tahapan penegakan hukum in abstracto oleh pembuat undang-undang, kedua, tahap aplikasi atau yudikatif, yaitu tahapan penerapan hukum pidana oleh aparat-aparat penegakan hukum mulai dari kepolisian sampai pada pengadilan, dan ketiga, yaitu pelaksanaan hukum pidana secara konkret oleh aparat-aparat pelaksana pidana/eksekusi kepada para pembuat tindak pidana atau melanggar hukum. ${ }^{21}$

Perihal penegakan hukum sebagaimana penjelasan di atas, penulis membatasi kajiannya hanya pada kedudukan permasalahan dalam rumusan masalah pertama pada tingkat penegakan hukum di tingkat kepolisian. Sebagai lembaga terdepan dalam penegakan hukum yang bersifat represif ketika telah terjadinya sebuah tindakan yang dinilai menyimpang dari koridor hukum.

Ditinjau dari kedudukan Audit Medis di atas dan penegakan hukum di kepolisian, diperoleh hasil penelitian bahwa, kedudukan Audit Medis dalam penegakan hukum tindak pidana kesehatan, pada kenyataannya tidak digunakan.

a. Bahwa Kewenangan penegakan tersebut dilaksanakan melalui mekanisme pengaduan atau laporan ke pihak kepolisian, Kewenangan kepolisian dalam proses pidana, sebagaimana dimaksud, dalam Pasal 102 ayat (1) dan Pasal 106 KUHAP, wajib segera melakukan tindakan penyelidikan atau penyidikan ketika mengetahui atau menerima laporan dan pengaduan tentang terjadinya suatu peristiwa yang patut diduga merupakan tindak pidana.

${ }^{21}$ Teguh Prasetyo, Op. Cit., hlm. 111. 
Penjelasan pasal di atas di dalam hal penegakan hukum menjadi jelas bahwa kepolisian sebagai lembaga penegak hukum yang menegakkan hukum pidana melalui mekanisme penyelidikan dan penyidikan atas dasar laporan atau pengaduan. Lalu dari pengertian ini, dapatkah Audit Medis menjadi bagian dalam penegakan hukum di kepolisian atau tidak. Inilah yang menjadi dasar dalam permasalahan kajian tesis ini.

Karena dalam setiap literatur tidak menjelaskan bahwa penegak hukum untuk menggunakan Audit Medis di bidang kesehatan sebagai sandaran dalam setiap bentukan penyelidikan dan penyidikan. Bahkan, ketika penulis melakukan penelitian hal ini ditegaskan oleh kepolisian bahwa tidak menggunakan Audit Medis dalam penegakan hukumnya khususnya di bidang medis ketika terjadi tindak pidana. ${ }^{22}$ Namun di sisi lain, berdasarkan pada penelitian penulis, profesi kesehatan dalam hal ini pihak kedokteran di Rumah Sakit pada bagian komite medis, menegaskan bahwa ketika terjadi komplain dari pihak mana pun juga yang merasa dirugikan, kemudian hal itu dilaporkan kepada pihak kepolisian tentu hal ini sangatlah keliru, karena bukan tidak mungkin bahwa semua pihak penegak hukum mengerti persoalan medis atau kesehatan. ${ }^{23}$ Persoalan ini menurut penulis menjadi bukti bahwa penegakan hukum dalam kacamata dan sudut pandang antara penegak hukum dan profesi medis saling berlawanan, hal ini tentu berkaitan dengan persoalan kebenaran dalam menentukan dan menemukan kesalahan atau kelalaian yang dilakukan oleh profesi medis dalam menuju sebuah keadilan.

b. Bahwa Dasar hukum Pelaksanaan Audit Medis, Audit Medis termaktub dalam UU Kedokteran pada Pasal 49 ayat (1), "setiap dokter dan dokter gigi dalam melaksanakan praktik kedokteran atau kedokteran gigi wajib menyelenggarakan kendali mutu dan kendali biaya." Ayat (2) dalam rangka pelaksanaan kegiatan sebagaimana dimaksud pada ayat (1) dapat diselenggarakan Audit Medis. Begitu pun dalam UU Rumah Sakit menekankan agar rumah sakit menyelenggarakan audit medis dan audit kinerja, adanya tindakan ini dalam rangka kualitas, perlindungan kepada pasien dan pemenuhan pelayanan rumah sakit. Berdasarkan pada bentukan UU di atas maka eksistensi Audit Medis menjadi suatu kegiatan penting dalam menilai setiap tindakan medis. Hal ini karena, Penjelasan undang-undang di atas mengisyaratkan bahwa secara UU perintah Audit Medis menjadi wajib dan tidak bisa ditinggalkan begitu pun bertumpu pada perlindungan pasien namun perihal ini tidak menjadi bagian penegakan bagi kepolisian ketika terjadi dugaan tindak pidana yang dilakukan oleh dokter atau tenaga medis.

c. Bahwa secara konteks doktrinal, Audit medis pun dilakukan karena ia merupakan standar ketentuan dalam hal penilaian setiap tindakan kedokteran, dalam melakukan tindakan medis di Rumah Sakit ataupun pada praktik sendiri. pelaksanaan Audit Medis tetap dilakukan demi Menjaga mutu atau kualitas,

22 Hasil Wawancara dengan Pihak Kepolisian, Polda Yogyakarta.

${ }^{23}$ Hasil Wawancara dengan Pihak Komite Medis Rumah Sakit Panti Rapih. 
perlindungan kepada pasien ${ }^{24}$ serta perbaikan pelayanan di rumah sakit. bagaimana kita dapat mengetahui daripada sebuah tindakan tenaga medis atau dokter di rumah sakit apakah hal itu berdasarkan pada standar profesi dan standar prosedur operasional di rumah sakit.25 Oleh sebab itu pelaksanaan Audit Medis tersebut, di rumah sakit mempunyai peran penting dan strategis dalam hal pelayanan medis kepada pasien di rumah sakit, terselenggaranya sebuah tindakan yang baik dan berpedoman pada standar operasional rumah sakit, semua itu dapat dilihat dalam mekanisme Audit Medis oleh komite medis di rumah sakit.

d. Penegakan hukum di kepolisian yang menggunakan pada bentukan Rekam Medis seperti yang tercantum pada UU Namun hal ini, menjadi kontra dari pihak rumah sakit dalam melihat mekanisme tersebut. karena apabila hanya bersandar pada rekam medis dapatkah hal itu menjawab semua persoalan, hal ini kenapa karena di satu sisi apakah semua tindakan dokter itu dapat dengan pasti tertulis dalam bentukan rekam medis ${ }^{26}$, karena hal yang tidak diinginkan bisa terjadi, seperti dokter lupa mencantumkan atau menuliskan tindakannya pada format rekam medis. Memang dalam ketentuan bahwa segala tindakan harus dicatat pada rekam medis. ${ }^{27}$

Persoalan di atas dapat dimengerti bahwa tindakan kepolisian yang bersandar kepada salah satu instrumen kesehatan, tentu sangat tidak memadai dalam mencari dan menemukan sebuah tindakan yang diduga sebuah pelanggaran pidana, hal ini kenapa, karena tentu penilaian terhadap rekam medis tersebut tidak bersifat menyeluruh dan valid, dan ini sangat berkaitan dengan penentuan salah atau tidaknya tindakan dokter kepada pasien dalam pelayanan kesehatan ketika terjadi komplain, atau merasa dirugikan dari segala tindakan medis yang di dapatkan di rumah sakit.

e. Alasan Pihak Kepolisian, tidak dapat digunakannya Audit Medis dari pihak kesehatan karena sebagaimana kita ketahui kesehatan atau kedokteran terdapat sebuah bentuk hubungan untuk saling melindungi teman sejawat, atau di dalam Kode Etik Kedokteran mengharuskan setiap dokter memelihara hubungan baik dengan teman sejawatnya sesuai makna atau butir dari lafal sumpah dokter yang mengisyaratkan perlakuan terhadap sejawatnya sebagai berikut: "Saya akan perlakukan teman sejawat saya sebagai mana saya sendiri ingin diperlakukan." Pernyataan di atas menurut penulis haruslah menyeimbangkan dan mendudukkan persoalan pada porsi yang sebenarnya, kita semua tahu bahwa dalam setiap tindakan medis yang dilakukan oleh dokter selalu berdasarkan pada bentukan itikad baik, dan juga bersandar pada dari sini dapat juga dimengerti bahwa tindakan dokter adalah untuk melindungi setiap manusia yang dilayani. Secara otomatis tindakan tersebut akan berbeda ketika dipertemukan dengan saling melindungi teman sejawat, ketika diduga salah satu temannya melakukan tindakan penyimpangan.

\footnotetext{
${ }^{24}$ Hasil wawancara dengan pihak IDI Cabang Yogyakarta.

${ }^{25}$ Fred Ameln, Op Cit., hlm. 92.

${ }^{26}$ Lihat Peraturan Menteri Kesehatan Republik Indonesia Nomor 269/Menkes/Per/Iii/2008 tentang Rekam Medis pada Bab III Pasal (5) dasar hukum tindakan pencacatan pada rekam medis.

${ }^{27}$ Wawancara dengan Pihak Rumah Sakit, Bethesdha Yogyakarta.
} 
Begitu juga dengan alasan bahwa saling melindungi teman sejawat pun dapat dibantahkan dengan segala tindakan oleh pihak komite medis seperti yang dijelaskan di bawah ini, ketika terjadi sebuah komplain, penyimpangan atau tindakan yang tidak dinginkan. Audit Medis melalui komite medis dapat melihat dan menelaah semua tindakan dokter yang dimaksud, apakah hal itu bertentangan dengan standar profesi atau standar prosedur operasional atau tidak. Standar Profesi dan standar prosedur operasional sebagai tolak ukur pada sebuah penilaian dan lebih objektif dalam melihat sebuah persoalan, bukan pada perlindungan teman sejawat yang berakhir pada penilaian subjektif.

Adapun sejauh manakah hasil Audit Medis dapat dipakai sebagai bahan pembuktian dalam tindak pidana di bidang medis.

a. Keterangan ahli dalam kaitannya dengan kedudukan Audit Medis, menurut dokter pada saat penulis melakukan penelitian, mengatakan bahwa Audit Medis itu merupakan hasil evaluasi atau kajian rekam medis dan beserta segala tindakan dokter yang dilakukan pada saat melakukan tindakan medis ${ }^{28}$ Kedudukan Audit Medis di atas dan kedudukan rekam medis menurut penulis merupakan bagian yang tak terpisahkan antar satu dengan lain sebagaimana dijelaskan di atas, karena penilaian menjadi benar dan akurat pada rekam medis ketika hal itu diukur berdasarkan standar profesi dan standar prosedur operasional. Hal ini mengapa karena semua tindakan medis atau tindakan pencatatan pada rekam medis merupakan bagian yang dilakukan oleh dokter atau tenaga medis. Keakuratan Audit Medis yang mana di dalamnya terdiri dari perkumpulan dokter atau ahli medis (mitra bestari), bentuk penilaian kepada tindakan dokter dan rekam medis berdasar pada bentukan standar profesi dan standar prosedur operasional. Bukan berdasarkan pada penilaian yang bersifat pribadi dan tak berdasar atau pada kedekatan emosional dalam melindungi teman sejawat.

b. Penjelasan ini juga dijelaskan oleh narasumber di Rumah Sakit Panti Rapih pada komite medis, bahwa kedudukan sumpah sudah pasti menjadi pengikat dan

${ }^{28}$ Hasil wawanccara dengan pihak komite medis RSU Bethesda. 
melekat pada diri dokter dalam setiap tindakannya. Kode etik sebagai jalan dalam hal bertindak, karena kode etik mengatur bagaimana seseorang itu bertindak sesuai dengan kewenangan dan kompetensinya ${ }^{29}$ Kekuatan sumpah menjadi mengikat bagi dokter dalam hal pembuatan Audit Medis. sumpah mengarahkan pada diri perlindungan manusia sejak masa pembuahan, maka Audit Medis menjadi jaminan mutu pelayanan kesehatan dan perlindungan keselamatan pasien dalam setiap tindakan tenaga kesehatan. Kode etik sebagai pengaturan konkret pengejewantahan sumpah kedokteran. Sumpah mengatur bagaimana bertindak pada tata kelakuan menuju pada sebuah perlindungan, dan etik adalah pengaturan pada kualitas, atau kompetensi serta kapasitas tenaga kesehatan. Tidaklah berbeda antara sumpah yang melekat pada diri dokter serta tujuan pembuatan Audit Medis pada komite medis. Oleh sebab itu sumpah yang mengikat pada dokter mempunyai implikasi yang sama pada Audit Medis dalam hal melindungi keselamatan pasien. maka dokter atau tenaga medis terikat pada sumpah dan kode etik kedokteran ketika dibuatnya Audit Medis.

Hasil Audit Medis ini menurut penulis sangatlah akurat dan dapat diterima sebagai bentukan pembuktian ketika terjadi penyimpangan, atau persoalan di bidang medis. Karena Audit Medis berdasar rekam medis dan penilaiannya pada ketentuan standar profesi dan standar prosedur operasional. Namun dalam bentuk apakah Audit Medis ini masuk sebagai bagian dalam pembuktian di persidangan. Menurut ketentuan KUHAP, Keterangan Ahli adalah keterangan yang diberikan oleh seseorang yang memilki keahlian khusus tentang hal yang diperlukan untuk membuat terang suatu perkara pidana guna kepentingan pemeriksaan"

Menurut KUHAP membedakan keterangan seorang ahli di persidangan dan keterangan ahli secara tertulis yang disampaikan di depan sidang pengadilan. Jika seorang ahli memberikan keterangan secara langsung di depan sidang pengadilan dan di bawah sumpah. Keterangan tersebut adalah alat bukti keterangan ahli yang sah. Sementara itu, jika seorang ahli di bawah sumpah telah memberikan keterangan tertulis di luar persidangan dan keterangan tersebut dibacakan di

${ }^{29}$ Hasil Wawancara dengan Pihak Komite Medis di Rumah Sakit Panti Rapih. 
depan sidang pengadilan, keterangan ahli tersebut merupakan alat bukti surat dan alat bukti keterangan ahli.

Ketentuan KUHAP di atas jika dihubungkan dengan permasalahan Audit Medis maka menjadi keterangan ahli dalam persidangan ketika hal itu disampaikan di depan sidang pengadilan, adapun ketika dibuat di bawah sumpah dan diberikan di luar persidangan, keterangan ahli tersebut merupakan alat bukti surat dan alat bukti keterangan ahli.

\section{Penutup}

Kedudukan Audit Medis dalam penegakan hukum pidana dapat diterapkan pada posisi penyelidikan dan penyidikan di kepolisian, namun dalam pelaksanaannya kepolisian tidak menggunakan Audit Medis sebagai bagian instrumen penegakan. Padahal kedudukan Audit Medis dinilai sangat penting dalam melihat sebuah permasalahan, karena di dalamnya terdapat sebuah bentukan peer group/mitra bestari atau perkumpulan para dokter yang ahli dibidangnya. Penilaian oleh bentukan ini akan lebih fair dan valid karena berbanding lurus pada pengertian standar profesi medis, dan standar prosedur operasional. Maka dari itu, kepolisian dalam hal penegakan hukum, seharusnya menjadikan Audit Medis sebagai bagian dari keterangan ahli pada bagian penyelidikan dan penyidikan di kepolisian, mengingat kedudukan Audit Medis dapat atau mampu membuat terang suatu permasalahan medis, dari segala bentuk sebab dan akibat.

Perihal pembuktian, Audit Medis tidak digunakan sebagai bagian dalam proses pembuktian penyelidikan dan penyidikan di kepolisian. Padahal kedudukan Audit Medis dapat dijadikan bahan pada keterangan ahli di kepolisian. Oleh sebab itu, diharapkan penegak Hukum, untuk dapat menjadikan Audit Medis sebagai bagian pembuktian di Kepolisian.

\section{Daftar Pustaka}

\section{Buku}

Buamona, Hasrul, Tunggung Jawab Pidana Dokter Dalam Kesalahan Medis, Diterbitkan atas kerjasama JHB-FORMASY-PARAMA Publishing, Yogyakarta, 2015. 
Buku Acuan Nasional, Pelayanan Kesehatan Material dan Neonatal, Penerbit JNPKKRPOGI, Jakarta, 2002.

Bunga Rampai tentang Medikal Malpraktik, Jilid IIA, URAIAN TEORITIS DAN KUTIPAN KEPUTUSAN TENTANG MEDICAL PRAKTICE, MAHKAMAH AGUNG RI, 1992.

Chazawi, Adam, Malpraktik Kedokteran, Penerbit Sinar Grfika, Jakarta, Cetakan Pertama, 2016.

Eddy, O.S. Hiariej, Prinsip-Prinsip Hukum Pidana, Penerbit Cahaya Atma Pustaka, Yogyakarta, 2014.

Elvandari, Siska, Hukum Penyelesaian Sengketa Medis, Penerbit Thafa Media, Cetakan I, Yogyakarta,

Gunadi, Ismu dan Jonaedi Efendi, Cepat dan Mudah memahami hukum pidana, Penerbit Kencana Prenada Media Group, Jakarta, 2014.

Hatta, Moh., Hukum Kesehatan \& Sengketa Medik, Penerbit Liberty Yogyakarta, Yogyakarta, 2013.

Hendrik, Etika E Hukum Kesehatan, Penerbit Buku Kedokteran EGC, Jakarta, 2011.

Is, Muhamad Sadi, Etika Hukum Kesehatan (Teori dan Aplikasinya di Indonesia).Penerbit Kencana, Jakarta, 2015.

Machmud, Syahrul, Penegakan Hukum dan Perlindungan Hukum Bagi Dokter yang diduga Melakukan Medikal Malpraktek, Penerbit Mandar Maju, Bandung, 2008.

Marpaung, Leden, Asas-Teori-Praktik Hukum Pidana, Penerbit Sinar Grafika, Jakarta, 2005.

Muntaha, Hukum Pidana Malpraktik (Pertanggungjawaban dan Penghapus Pidana) Penerbit Sinar Grafika, Jakarta, 2017.

Muhammad, Rusli, Hukum Acara Pidana Kontemporer, Penerbit PT Citra Abadi Bakti, Bandung, 2007.

Prasetyo, Teguh, Kriminalisasi dalam hukum pidana, Penerbit Nusa Media, Bandung, 2010 Prasetyo, Teguh, Hukum Pidana Materil, Penerbit Kurnia Kalam Yogyakarta, Yogyakarta, 2005.

Pujiyono, Eko, Keadilan Dalam Perawatan Medis (Penerapan Prinsip Otonomi Pasien : Teori Hukum E Praktik di Pengadilan, Penerbit PT CITRA Aditya Bakti, Bandung, 2017.

Remmlink, Jan, Hukum Pidana, Penerbit PT Gramedia Pustaka Utama, Jakarta, 2003.

Seran, Marel dan Anna Maria Wahyu Setyowati, Dilema Etika Dan Hukum Dalam Pelayanan medis, Penerbit Cv. Mandar Maju, 2010.

Siswati, Sri, Etika dan Hukum kesehatan (Dalam Prespektif Undang-undang Kesehatan), PT Raja Grafindo, Jakarta. 2013. 
Supriadi, Etika \& Tanggung Jawab Profesi Hukum di Indonesia, Penerbit Sinar Grafika, Jakarta, 2014.

Suryadhimirtha, Rinanto, Hukum Malpraktik Kedokteran, Penerbit Total Media, Yogyakarta, 2011.

Sutarno, Hukum Kesehatan (Eutanasia, Keadilan dan Hukum Positif di Indonesia), Penerbit Setara Press, Malang, Jatim, 2014.

Triwibowo, Cecep, Etika dan Hukum Kesehatan, Penerbit Nuha Medika, Yogyakarta, 2014

Wiyanto, Roni, Asas-Asas Hukum Pidana, Penerbit CV.Mandar Maju, Bandung, 2012.

Yunanto, Ari dan Helmi, Hukum Pidana Malpraktik Medik (Tinjauan dan Perspektif Medikolegal), Penerbit Andi, Yogyakarta, 2010.

\section{Undang-Undang}

Undang-Undang Republik Indonesia Nomor 44 Tahun 2009 tentang Rumah Sakit.

\section{Internet}

Artikel Muhajir Siregar Rekam Meds dan Audit Medis. https://rsadministrasi. wordpress.com/2015/12/22/permasalahan-rumah-sakit/

http:/ /megapolitan.kompas.com/read/2017/09/22/17300811/rs-mitrakeluarga-bayi-debora-tak-masuk-picu-karena-belum-stabil

PeraturanMenteriKesehatanRepublikIndonesiaNomor755/Menkes/P/Iv/2011Te ntangPenyelenggaraanKomiteMedikDiRumahSakit(http://www.flevin.c om/id/lgso/legislation/Mirrr/czozMToiZDlibisyMDExJmY9Ym4yNTkt MjAxMS5wZGYmanM9MSI7.pdf) 